\title{
Environmental and Health Education for School-Age Children: A Transdisciplinary Approach ${ }^{1}$
}

\section{Educação Ambiental e em Saúde para Escolares de Primeiro Grau: Uma Abordagem Transdiciplinar}

\section{Virginia T. Schall}

\section{SCHALL, V. T. Environmental and Health Education for School-Age Children: A}

Transdisciplinary Approach. Cad. Saúde Públ., Rio de faneiro, 10 (2): 259-263, Apr/fun, 1994. A brief critical analysis and suggestion for guidelines concerning environmental and health education in the elementary school are presented from the viewpoint of emerging pedagogic experiences and theoretical philosophical reflections.

The major points discussed are: the importance of transdisciplinarity, the enhancement of participatory education where technical knowledge and popular wisdom meet, the planning and execution of concrete experiences which stimulate the sensations of pleasure and of admiration for nature and life, the analysis and the search for a solution to problems affecting the local reality of pupils without losing sight of global issues. A major priority is investment in teacher training, stimulating acquisition of knowledge through creative practice and formation of a critical awareness, essential for the school to clearly show its commitment to a future of greater social equality and harmony in our relationship to the environment. Key words: Environmental Education; Health Education; Elementary School; Child Education

\section{HEALTH AND EDUCATION: A BRIEF ANALYSIS}

During the 1980s, the World Health Organization (WHO) began emphasizing control of morbidity caused by various parasitie diseases including schistosomiasis and others (WHO, 1985). Thus, the WHO started to stimulate primary health care programs including chemotherapy and manipulation and alteration of the environment requiring participation by the population, a goal for which education is essential.

${ }^{1}$ The author's quoted works are been supported by the UNDP/World Bank/WHO Special Programme for Research and Training in Tropical Diseases and CNPq. the Brazilian National Research Council.

${ }^{2}$ Laboratório de Educação Ambiental e em Saúde, Departamento de Biologia, Instituto Oswaldo Cruz. Caixa Postal 926, Rio de Faneiro, RF, 20001-970, Brasil.
This process requires reflection on the importance of health education and its relationship to environmental issues.

When discussing health education, an initial theoretical discussion is necessary on the two areas at issue, i.e., education and health. Both are conditioned by a historical process orienting concept and practice.

The role of education both inside and outside school is to build knowledge in such a way as to allow everyone to exercise full, participatory citzenship (Namo de Mello, 1974). However, democratization of education is an essentially political issue rather than merely a pedagogic one, a fact which is conditioned by the distribution and acquisition of wealth, going beyond the limits of educational activity and those of the school itself. This underscores the obstacles faced by any educational program in Brazil in view of government inertia in relation to urgent social change, without which any initiative will always be of limited reach.

One cannot hardly believe that education alone is capable of promoting changes at the 
structural level of society. However, education plays the fundamental role of favoring a critical reassessment of content and therefore of opening perspectives for demands in a democratic sense, i.e., in the sense of greater participation in choosing one's own destiny and managing the social context.

History points to an evolution from traditional health education to more recent innovative proposals. The traditional view determines what should be done and learned without considering a population's reality and felt health needs (Carvalho, 1978). Thus, the objective of traditional Health Education is to promote hygienie habits, basic child care, the use of cleaning materials and procedures, and adequate nutrition, emphasizing the question of sickness either by fostering preventive attitudes or recognition of initial signs of illness and awareness of treatment options (Tatochenko, 1979).

Increased social awareness has revealed the inadequacy of this type of education as to the following: 1) links with political interests other than those of the populations themselves; 2) its technical character, incapable of promoting changes in attitude by operating solely on the basis of vertically transmitted scientific knowledge; and 3) historical inertia, fossilized in outdated educational practices and contents.

Effective Health Education requires recognition of popular wisdom and practice ni search of solutions to problems, a steady updating through continuous influx of constantly changing technical-scientific information, and emphasis on health promotion and improvement of quality of life.

This implies a critical perception and attitude on the part of the educator, a command over relevant information in his/ her area and intrinsic motivation for the work he/she carries out.

It is of fundamental importance that educators be involved in participatory education where technical knowledge and popular wisdom complement each other knowledge is not produced exclusively by those who teach but is also based on practice: "knowledge is born and develops as people reflect on the experiences lived in all practices"(Freire, 1979).

Approaching the concept of health and illness in the school thus generates reflection on the various dimensions involved in these concepts, and on their complex and multifaceted nature.

According to Novaes (1979), health and illness are much more historically situated social values than a simple expression of the body's biological context (in general) in a given environment, and they should thus be interpreted in terms of their historical aspect.

Considering that disease occurs in a given environment, Rouquayrol (1988) emphasizes that the final state leading to a disease is the result of synergistic action amongst a multiplicity of political, economic, social, cultural, psychological, genetic, biological, physical and chemical factors.

To formulate a concept of disease is not simply a matter of knowing how to define it. It implies an understanding of its history, its consequences, and especially its complex determinants which the educational system often reduces to simple etiological agent-host interactions.

\section{AN ENVIRONMENTAL PERSPECTIVE OF HEALTH EDUCATION}

Reforms in school curricula starting in the late 1980s indicate a new view of health, seek articulation with other fields, and contemplate the environmental and socioeconomic aspects related to health.

Now, in the early 1990s, withan increased worldwide awareness as to the effects of ecological imbalance on the human species, health is being considered within a broader context, contemplating its relationship to both the physical and social environment. This approach has led to changes in school curricula content and has sparked new attitudes in teachers. Hopefully, this will be not merely a passing trend but an effective, longlasting advance in education.

An broadened concept of Health 
Education considers the individual a real ecosystem or microcosm. His body is a microbiotic system which or may not live in harmonious association. When a disturbance or imbalance occurs amongst elements of a biological system or between individual and their environment, the result is what we call disease.

If man is understood as an ecosystem integrated with the total environment, he will develop positive values, attitudes and relations with this environment only if he also develops these positive values towards himself.

Thus, from the onset, it is vitally important to stimulate a positive self-image in children, leading them to value themselves and to perceive that they are part of a larger context.

Children should learn that each action they perform may provoke a reaction in somebody else or in the environment, which in turn will probably produce a response.

Knowing the facts and concepts about the environment helps a child to acquire undestanding and to develop social awareness (positive attitudes) which will affect behavior (necessary actions) toward the environment as whole.

It is essential to help pupils to develop responsibility in terms of conservation of their own body, their house, their world. And this process will be sucesful only if it occurs in an affective climate without external impositions but offered with pleasure and understanding. Thus, the approach to health in the school should involve the affective and cognitive domains. Side by side with concrete and direct experiences, the acquisition of new information and of essential facts can situate classroom studies in a creative perspective, favoring the discovery of certain phenomena by the pupils themselves.

It is necessary to alternate situations of teaching about the problems and their solutions with practical experiences that may permit children to develop the "sense of wonder" (Rachel Carson apud Tanner, 1978), which means love for one's existence on a planet so full of wealth and fascinating landscapes.

This positive side of Environmental Education should be counterbalanced with information about the threats endangering natures, since it is important to learn to deal with these facts.

One of the strategies that could be used in the school is the stimulation of children to become involved in the environmental problems of their own community, searching for coletive solutions.

This emphasizes the role of the school, in which the educational process has a better guarantee of continuity and consistency, since the educational programs included in campaigns are of a transitory nature and utilize only mass communication media, with a consequent reduction of effectiveness.

\section{IMPORTANCE OF HEALTH EDUCATION AND TEACHER FORMATION IN THE ELEMENTARY SCHOOL}

Considering the low education level of most of the Brazilian population and the high drop-out rate, children are likely to be found in school only in the first grades of elementary school, when Health Education is of the greatest importance and can play a highly valuable role.

As pointed out earlier, for an educational program to be successful, it is necessary to consider the reality of the students and of their community, their habits, beliefs, cognitive characteristics, interests and motivations. When addressing children and adolescents, it is important to be alert to their developmental phase, to investigate their intuitive concepts of health and sikness, their perception of reality, so as to avoid any dissonance, conflict or inefficacy of information.

For the process to be permanent and not simply of an interventionist nature, it is necessary to invest in teacher training, stimulating the formation of a critical 
conscience. Thus, the teacher, and not somebody from outside the community will trigger an enriching educational action though a type of work is also political in that "learning about health is to learn to live", as recommended in the book "Saúde como compreensão de vida" ("Health as an understanding of life") coordinated by Hortência de Hollanda (1981). From this perspective, technical information should be associated with a discussion of the way of life and the rights of citizens, of a participation and organization that will lead to the conquest of rights to public services, to work and well-being, as suggested in the chapter "For an understanding of health":

"No matter how simple they may appear to be, the perceptions of the pupils are paths that will lead them to the necessary knowledge about health. Starting from these perceptions, they will become aware of the relations existing in their community or region between the ways of life and the level of health, to the discovery and categorization of the factors that condition health or sickness, to an understanding of the world that surrounds them, where not only people but also other living beings such as animals, plants and mocroorganisms, hare with them the space for life, revealing the same basic needs for food and shelter and behaving with remarkable powers for adaptation and for the struggle for survival". (Hollanda, 1981: 20-21)

For this perspective to be reached in the schools, it is necessary to offer courses to teachers, since, as observed earlier, their pedagogic efficiency and broad and critical vision of the health question is essential to motivate the participating and creative action of the students.

The experience of Schall et al. $(1987 ; 1993)$ has demonstrated that training courses including a combination of theoretical classes and practical activities are more effective. Thus, basic content on health should be combined with texts on teacherpupil relations, pedagogic methods and the use of artistic and cultural resources. After each unit, the teachers should demonstrate how to teach about health using different creative activities such as games, stories, dramatization, puppet theater, shows, excursions and handcraft techniques, all of them related to the health questions of the community to which the school belongs.

It is important to stimulate teachers to plan and execute practical projects together with the students. Projects that investigate some health problems wich are relevant to the students and to the school region and including actions and alternatives for solutions represent the proposal of the Laboratory of Environmental and Health Education (Department of Biology Oswaldo Cruz Institute - Oswaldo Cruz Foundation). The teachers are stimulated to recor their experience, to accompany it by systematic evaluations and to present it at scientific-pedagogic events. Thus, both teachers and pupils are stimulated to work creatively, developing and valuing the attitude of scientific observation and analysis of phenomena, determining the effect of their practice through the evaluations and becoming affectively involved with their schoolmates and the environment. In this respect, by intermingling with the other disciplines in the curriculum, environmental and health education brings a new dimension to the school, emphasizing human relations and the interaction of man with the environment from a harmonious and dynamic perspective of a commitment to social justice.

\section{RESUMO}

\section{SCHALL, V. T. Educação Ambiental e em Saúde para Escolares de Primeiro Grau: Uma Abordagem Transdisciplinar. Cad.} Saúde Públ., Rio de Janeiro, 10 (2): 259-263, abr/jun, 1994.

$\mathrm{O}$ artigo apresenta uma breve análise crítica e sugestões quanto à orientação da educação ambiental e em saúde na escola de primeiro grau, baseado em experiências pedagógicas recentes e algumas reflexões teóricofilosóficas. 
São discutidos no texto: a importância da transdiciplinaridade; da educação participativa na qual os conhecimentos populares são considerados ao se construir novos conceitos científicos; o planejamento de experiências concretas que estimulem sensações de prazer e admiração pela natureza e pela vida; a análise e busca de soluções para problemas que afetam a realidade local dos alunos, sem perder de vista as questões globais. Aponta-se como fundamental o investimento na formação dos professores, através de cursos e oficinas criativas, que associem a construção de novos conhecimentos à reflexão crítica sobre o papel da escola que deve estar comprometida com a busca de maior igualdade social e manutenção do equilíbrio nas relações entre o homem e a natureza, abrindo espaço para o exercício da cidadania entre os alunos.

Palavras-Chave: Educação Ambiental;

Educação em Saúde; Escola de Primeiro Grau; Educação Infantil

\section{REFERENCES}

CARVALHO, A. I., 1978. Saúde e educação de base: Algumas notas. Saúde em Debate, 7: 61-65.

FREIRE, P., 1979. Educação e Mudança. Rio de Janeiro: Paz e Terra.

HOLLANDA, H. (Org.), 1981. Saúde como Compreensão de Vida. Rio de Janeiro: PREMEN/MEC/SEPS/FENAME.
NAMO DE MELLO, G., 1974. Observações da interação professor-aluno: uma revisão crítica. Cadernos de Pesquisa, 12: 19-27.

NOVAES, H. M. D., 1979. A Puericultura em Questão. Tese de Mestrado, São Paulo: Universidade de São Paulo.

ROUQUAYROL, M. Z., 1988. Epidemiologia e Saúde. Fortaleza: UNIFOR.

SCHALL, V. T.; JURBERG, P.; ALMEIDA, E. M.; CASZ, C.; CAVALCANTE, F. G. \& BAGNO, S., 1987. Educação em saúde para alunos de primeiro grau. Avaliação de material para ensino e profilaxia da esquistossomose. Revista de Saúde Pública, 21: 387-404.

SCHALL, V. T.; SANTOS, M. G.; PINTODIAS, A. G. \& MALAQUIAS, M. L. G., 1993. Educação em saúde em escolas públicas de $1^{\circ}$ grau da periferia de Belo Horizonte, $M G$, Brasil. I. Avaliação de um programa relativo à esquistossomose. Revista do Instituto de Medicina Tropical de São Paulo, 35: 563-572.

TANNER, R. T., 1978. Educação Ambiental. São Paulo: Summus/EDUSP.

TATOCHENCO, V., 1979. Educação Sanitária. A Saúde no Mundo, 32: 24-28.

WHO, (World Health Organization), 1985. The Control of Schistosomiasis. Geneva: WHO. (Technical Report Series, 728) 